\title{
Detection of Exosomal miRNAs in the Plasma of Melanoma Patients
}

\author{
Susan R. Pfeffer ${ }^{1,+}$, Kenneth F. Grossmann ${ }^{2,+}$, Pamela B. Cassidy ${ }^{3}$, Chuan He Yang ${ }^{1}$, \\ Meiyun Fan ${ }^{1}$, Levy Kopelovich ${ }^{4}$, Sancy A. Leachman ${ }^{3}$ and Lawrence M. Pfeffer ${ }^{1, *}$ \\ Received: 3 August 2015; Accepted: 4 December 2015; Published: 17 December 2015 \\ Academic Editors: Takahiro Ochiya and Ryou-u Takahashi \\ 1 Department of Pathology and Laboratory Medicine, Center for Cancer Research, \\ University of Tennessee Health Science Center, 19 South Manassas Street, Memphis, TN 38163, USA; \\ spfeffer@uthsc.edu (S.R.P.); cyang@uthsc.edu (C.H.Y.); mfan2@uthsc.edu (M.F.) \\ 2 Department of Oncology, University of Utah, Salt Lake City, UT 84112, USA; \\ kenneth.grossmann@hci.utah.edu \\ 3 Department of Dermatology, Oregon Health \& Science University, Portland, OR 97239, USA; \\ cassidyp@ohsu.edu (P.B.C.); leachmas@ohsu.edu (S.A.L.) \\ 4 Department of Medicine, Weill Cornell College of Medicine, New York, NY 10065, USA; \\ kopelovichl@gmail.com \\ * Correspondence: LPFEFFER@UTHSC.EDU; Tel.: +1-901-448-7855; Fax: +1-901-448-3910 \\ $\dagger$ These authors contributed equally to this work.
}

\begin{abstract}
MicroRNAs (miRNAs) are a class of 22-25 nucleotide RNAs that control gene expression at the post-transcriptional level. MiRNAs have potential as cancer biomarkers. Melanoma is a highly aggressive form of skin cancer accounting for almost $4 \%$ of cancers among men and women, and $\sim 80 \%$ of skin cancer-related deaths in the US. In the present study we analyzed plasma-derived exosomal miRNAs from clinically affected and unaffected familial melanoma patients (CDKN2A/p16 gene carriers) and compared them with affected (nonfamilial melanoma) and unaffected control subjects in order to identify novel risk biomarkers for melanoma. Intact miRNAs can be isolated from the circulation because of their presence in exosomes. A number of differentially regulated miRNAs identified by NanoString human V2 miRNA array were validated by quantitative PCR. Significantly, miR-17, miR-19a, miR-21, miR-126, and miR-149 were expressed at higher levels in patients with metastatic sporadic melanoma as compared with familial melanoma patients or unaffected control subjects. Surprisingly, no substantial differences in miRNA expression were detected between familial melanoma patients (all inclusive) and unaffected control subjects. The miRNAs differentially expressed in the different patient cohorts, especially in patients with metastatic melanoma, may play important roles in tumor progression and metastasis, and may be used as predictive biomarkers to monitor remission as well as relapse following therapeutic intervention.
\end{abstract}

Keywords: miRNAs; melanoma; exosomes; metastasis

\section{Introduction}

MicroRNAs (miRNAs) are an abundant class of small RNAs that control gene expression at the post-transcriptional level through degradation or repression of mRNA translation [1]. MiRNAs are able to regulate the expression of multiple targets by binding to the $3^{\prime}$-untranslated regions of genes. Emerging evidence suggests that miRNAs are involved in critical biological processes, including development, differentiation, apoptosis, proliferation and antiviral defense [2]. Most importantly, aberrant expression of miRNAs appears to be causatively linked to the pathogenesis of cancer [3]. Thus, miRNAs have potential as risk biomarkers, particularly following therapeutic intervention. 
Exosomes are small $(30-100 \mathrm{~nm})$ extracellular vesicles that are produced by a wide variety of cell types, including tumor cells [4]. Although exosomes were originally considered to be cellular waste products, recent studies have demonstrated that they promote intercellular communication and immunoregulatory processes by shuttling proteins, lipids, and miRNAs between cells $[5,6]$. Moreover, intact miRNAs can be isolated from the circulation in significant quantities despite the presence of high levels of RNase activity because of their presence in exosomes $[7,8]$. The remarkable stability of circulating exosomal miRNAs makes them candidates to monitor disease progression in a variety of cancers.

Skin cancer is the most common human cancer. The incidence of melanoma, the most lethal skin cancer, is one of the few cancers in the U.S. that continues to rise [9]. Melanoma is a highly aggressive form of skin cancer that accounts for almost $5 \%$ of cancers among men and women, and $\sim 80 \%$ of skin cancer-related deaths in the US. The clustering of several melanomas within a single family, several independent primary melanomas in a single individual, and co-incidence of several melanomas and other cancers such as pancreatic cancer in the same family are all associated with inheritance of germline mutations in a high-penetrance melanoma susceptibility gene [10]. The most common high-penetrance melanoma predisposition gene is cyclin-dependent kinase inhibitor $2 \mathrm{~A}$, which encodes two independent predisposition genes, CDKN2A/p16 and CDKN2A/ARF. CDKN2A mutations occur in approximately $20 \%-40 \%$ of melanoma-prone families worldwide [11,12]. Variable rates of mutation have been found in sporadic melanomas, in some studies being as high as $50 \%$ in primary lesions [13]. The CDKN2A gene locus generates two proteins through alternate reading frames: $\mathrm{p} 16^{\mathrm{INK} 4 \mathrm{a}}$ and $\mathrm{p} 14^{\text {arf }}$. The $\mathrm{p} 16^{\mathrm{INK} 4 \mathrm{a}}$ protein binds to CDK4 and CDK6, inhibiting their ability to phosphorylate the retinoblastoma protein. The $\mathrm{p} 14^{\text {arf }}$ protein stabilizes the tumor suppressor protein p53. Collectively, these CDKN2A gene products are potent tumor suppressors that play distinct but critical roles in cell cycle progression and apoptosis [14]. Heterozygous loss of p16 $6^{\text {INK4a }}$ function is sufficient to confer a $67 \%$ lifetime risk of melanoma [15].

According to the National Cancer Institute, in 2015 an estimated 76,100 new melanoma cases will be diagnosed and 9710 deaths will occur in the US. Identifying early biomarkers for melanoma would enable discovery of potential targets and presumably agents for early intervention in persons at risk of developing melanoma. A noninvasive screening tool to identify patients with a predisposition to melanoma is presently lacking. Whole blood holds several advantages as a biomarker specimen, most notably because sampling and processing is much simpler than that of skin. In this regard it holds significant potential as a point-of-care test, which would be attractive in determining an ideal cancer-screening tool.

We previously showed that gene expression profiles are altered in phenotypically normal skin fibroblasts from familial melanoma families with distinct CDKN2A/p16 mutations (DKN2A:c.377T>A (p.V126D) and CDKN2A:c.259G>T (p.R87P)) when compared to skin fibroblasts from normal controls [16]. Furthermore, UV-irradiation of skin fibroblasts from such familial melanoma cohorts resulted in specific alterations in the expression of genes that regulate cell cycle and DNA damage response, and similar alterations in gene expression were also observed in melanoma lesions. In the present study, we investigated whether exosomal-derived miRNAs in the plasma from both clinically symptomatic and asymptomatic familial (CDKN2A:c.377T >A (p.V126D)) and sporadic melanoma patients, including unaffected family members, may be used as prognostic biomarkers to identify individuals at high risk of developing melanoma. However, this proof of principle experiment did not identify miRNAs specifically dysregulated in plasma-derived exosomes from familial melanoma patients. Nonetheless, several miRNAs were differentially expressed in patients with metastatic disease, not only in melanoma tumor tissue but also in plasma-derived exosomes. This result substantiates the finding of miRNA dysregulation in metastatic melanoma [17-19]. These findings form the basis for future studies on their applicability as diagnostic and prognostic biomarkers in melanoma. 


\section{Results}

2.1. Characterization of miRNA Expression in Plasma-Derived Exosomes from Patients with a Predisposition to Melanoma and Patients with Metastatic Melanoma

We performed miRNA profiling on RNA prepared from plasma-derived exosomes from four specific patient cohorts. The general patient information is shown in Table 1. Cohort A comprised 8 clinically affected individuals from a single large family, who carried a CDKN2A/p16 (CDKN2A:c.377T>A (p.V126D)) mutation but were free of disease at the time of blood draw. Cohort B comprised 5 individuals from the same family as in Cohort A with CDKN2A/p16 mutations, but with no history of melanoma at the time of this study. Cohort $C$ comprised 13 spouse controls in the same kindred as A and B above, and Cohort D consisted of 10 non-related metastatic melanoma patients with currently active disease. We hypothesized that genetically predisposed individuals such as those who carried a CDKN2A/p16 mutation might share the expression profile with individuals having sporadic metastatic melanoma.

Table 1. General patient information.

\begin{tabular}{|c|c|c|c|c|}
\hline Cohort & Age & Gender & p16 Mutation Status & Melanoma Diagnosis \\
\hline A1 & 37 & M & 377T>A (p.V126D) & $\mathrm{N}$ \\
\hline $\mathrm{A} 2$ & 40 & M & $377 \mathrm{~T}>\mathrm{A}(\mathrm{p} \cdot \mathrm{V} 126 \mathrm{D})$ & $\mathrm{N}$ \\
\hline A3 & 37 & M & $377 \mathrm{~T}>\mathrm{A}(\mathrm{p} . \mathrm{V} 126 \mathrm{D}))$ & $\mathrm{N}$ \\
\hline A4 & 46 & M & $377 \mathrm{~T}>\mathrm{A}(\mathrm{p} . \mathrm{V} 126 \mathrm{D})$ & $\mathrm{N}$ \\
\hline A5 & 64 & $\mathrm{~F}$ & $377 \mathrm{~T}>\mathrm{A}(\mathrm{p} . \mathrm{V} 126 \mathrm{D})$ & $\mathrm{N}$ \\
\hline B1 & 86 & M & $377 \mathrm{~T}>\mathrm{A}(\mathrm{p} \cdot \mathrm{V} 126 \mathrm{D})$ & $\mathrm{Y}$ \\
\hline B2 & 56 & M & $377 T>A(p \cdot V 126 D)$ & Y \\
\hline B3 & 83 & M & $377 T>A(p \cdot V 126 D)$ & Y \\
\hline B4 & 66 & $\mathrm{~F}$ & $377 \mathrm{~T}>\mathrm{A}(\mathrm{p} . \mathrm{V} 126 \mathrm{D})$ & $\mathrm{Y}$ \\
\hline B5 & 50 & M & $377 \mathrm{~T}>\mathrm{A}(\mathrm{p} . \mathrm{V} 126 \mathrm{D})$ & $\mathrm{Y}$ \\
\hline B6 & 39 & $\mathrm{~F}$ & $377 T>A(p \cdot V 126 D)$ & Y \\
\hline B7 & 42 & $\mathrm{~F}$ & $377 \mathrm{~T}>\mathrm{A}(\mathrm{p} \cdot \mathrm{V} 126 \mathrm{D})$ & $\mathrm{Y}$ \\
\hline B8 & 52 & $\mathrm{~F}$ & $377 \mathrm{~T}>\mathrm{A}(\mathrm{p} \cdot \mathrm{V} 126 \mathrm{D})$ & Y \\
\hline $\mathrm{C} 1$ & 68 & $\mathrm{M}$ & negative & $\mathrm{N}$ \\
\hline $\mathrm{C} 2$ & 40 & $\mathrm{~F}$ & negative & $\mathrm{N}$ \\
\hline $\mathrm{C} 3$ & 41 & M & negative & $\mathrm{N}$ \\
\hline $\mathrm{C} 4$ & 46 & M & negative & $\mathrm{N}$ \\
\hline C5 & 45 & $\mathrm{~F}$ & negative & $\mathrm{N}$ \\
\hline C6 & 36 & M & negative & $\mathrm{N}$ \\
\hline $\mathrm{C} 7$ & 58 & $\mathrm{M}$ & negative & $\mathrm{N}$ \\
\hline $\mathrm{C} 8$ & 63 & $\mathrm{M}$ & negative & $\mathrm{N}$ \\
\hline C9 & 88 & M & negative & $\mathrm{N}$ \\
\hline C10 & 34 & $\mathrm{~F}$ & negative & $\mathrm{N}$ \\
\hline C11 & 36 & F & negative & $\mathrm{N}$ \\
\hline C12 & 40 & F & negative & $\mathrm{N}$ \\
\hline C13 & 68 & $\mathrm{~F}$ & negative & $\mathrm{N}$ \\
\hline D1 & 50 & M & Not tested & met mel \\
\hline D2 & 48 & $\mathrm{~F}$ & Not tested & met mel \\
\hline D3 & 38 & M & Not tested & met mel \\
\hline D4 & 55 & M & Not tested & met mel \\
\hline D5 & 34 & M & Not tested & met mel \\
\hline D6 & 81 & M & Not tested & met mel \\
\hline D7 & 82 & $\mathrm{~F}$ & Not tested & met mel \\
\hline D8 & 40 & M & Not tested & met mel \\
\hline D9 & 40 & M & Not tested & met mel \\
\hline D10 & 55 & M & Not tested & met mel \\
\hline
\end{tabular}

In brief, the miRNA expression data from the 36 samples was analyzed with nSolver software to identify alterations in miRNA expression. Among the 700 human miRNAs examined, 75 miRNAs 
were detected in plasma-derived exosomes from more than half of the patients. The 50 miRNAs that showed highest total reads (most abundant) in the exosomes of the 36 patient samples were then subjected to unsupervised hierarchal clustering with the expression heat maps of the individual patient samples shown in Figure 1. The twenty most variable miRNAs among all samples were then further validated by qPCR analysis to examine their differential expression within the four patient cohorts described in Table 1 . These miRNAs included let-7b, let-7g, miR-17, miR-19a, miR-19b, miR-20b, miR-21, miR-23a, miR-29a, miR-92a, miR-125b, miR-126, miR-128, miR-137, miR-148a, miR-149, miR-199a, miR-221, miR-222 and miR-423 (Table 2).
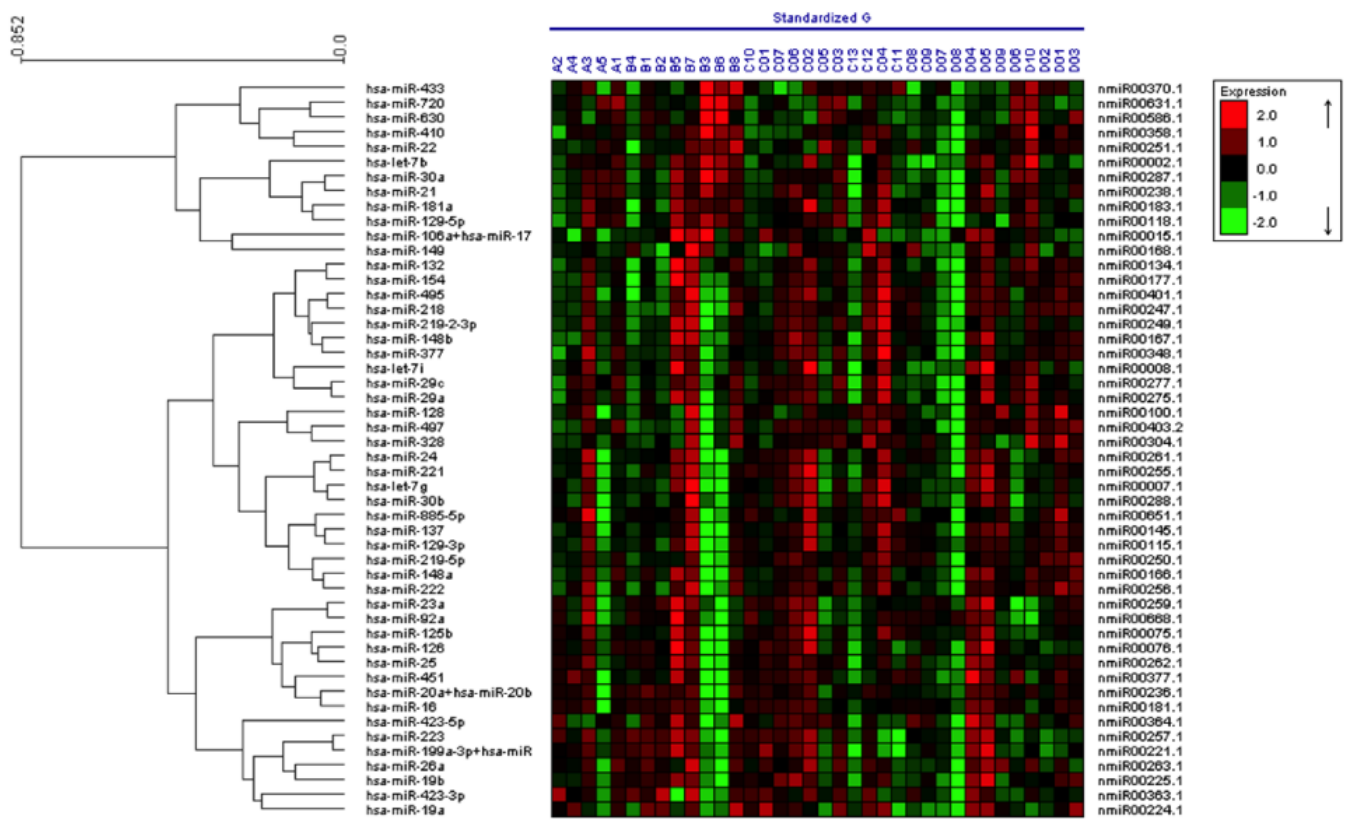

Figure 1. Characterization of miRNA expression in plasma-derived exosomes from individuals with a genetic predisposition to melanoma (all inclusive), spouse controls and patients with sporadic metastatic melanoma. RNA was prepared from plasma-derived exosomes from the patient cohorts listed in Table 1, and miRNA expression profiling was conducted on the nCounter Analysis System using the human V1 miRNA assay kit.

Table 2. Primers used for miRNA expression.

\begin{tabular}{cc}
\hline hsa-let-7b & TGAGGTAGTAGGTTGTGTGGTT \\
hsa-let-7g-5p & TGAGGTAGTAGTTTGTACAGTT \\
hsa-miR-125b & TCCCTGAGACCCTAACTTGTGA \\
hsa-miR-126 & TCGTACCGTGAGTAATAATGCG \\
hsa-miR-128 & TCACAGTGAACCGGTCTCTTT \\
hsa-miR-137 & TTATTGCTTAAGAATACGCGTAG \\
hsa-miR-148a & AAAGTTCTGAGACACTCCGACT \\
hsa-miR-149 & TCTGGCTCCGTGTCTTCACTCCC \\
hsa-miR-17 & CAAAGTGCTTACAGTGCAGGTAG \\
hsa-miR-199a-5p & CCCAGTGTTCAGACTACCTGTTC \\
hsa-miR-19a & TGTGCAAATCTATGCAAAACTGA \\
hsa-miR-19b & TGTGCAAATCCATGCAAAACTGA \\
hsa-miR-20b & TAAAGTGCTTATAGTGCAGGTAG \\
hsa-miR-21 & TAGCTTATCAGACTGATGTTGA \\
hsa-miR-221 & AGCTACATTGTCTGCTGGGTTTC \\
hsa-miR-222 & AGCTACATCTGGCTACTGGGT \\
hsa-miR-23a & ATCACATTGCCAGGGATTTCC \\
hsa-miR-29a & TAGCACCATCTGAAATCGGTTA \\
hsa-miR-423-5p & TGAGGGGCAGAGAGCGAGACTTT \\
hsa-miR-92a & TATTGCACTTGTCCCGGCCTGT \\
\hline
\end{tabular}




\subsection{Detection of Circulating miRNA in Plasma-Derived Exosomes}

Since there are no known control or house-keeping microRNAs in exosomes, we adopted the strategy of using spiked-in C. elegans miRNAs directly into Qiazol prior to RNA extraction as normalizing controls [20]. To determine whether our miRNA assays by qPCR were within the linear range of detection, a reference standard Cel-39 was spiked into Qiazol at $0.05 \mathrm{fmol} / \mathrm{mL}$ and $0.0005 \mathrm{fmol} / \mathrm{mL}$ prior to RNA extraction, and the expression of miR-21, miR-92b and miR-126 in plasma-derived exosomes was determined. These assays demonstrated the appropriate miRNA expression levels relative to the known quantity of spiked-in Cel39, demonstrating that our qPCR assay conditions for miRNAs were within the linear range.

We then examined the expression of circulating miRNAs by qPCR using the RNAs derived from the original cohort, plus an additional 3 metastatic melanoma patient samples. Thus, we analyzed miRNA expression in 13 individuals with metastatic melanoma, 13 control volunteers, 5 individuals with the p16 mutation (CDKN2A:c.377T>A (p.V126D)) but with no clinical evidence of melanoma incidence, and 8 individuals with the p16 mutation with melanoma. We subjected the qPCR data on the circulating miRNAs to statistical analysis as shown in Tables $3-5$ and presented as "box plots" in Figures 2 and 3. In Table 3 we compared the expression levels of these miRNAs between individuals with the CDKN2A:c.377T>A (p.V126D) mutation to those of normal volunteers, and found that there were no statistically significant differences between expression of any of the 20 exosomal miRNAs measured. In Table 4 and Figure 2 we show the comparison in miRNA expression between individuals with the p16 mutation (CDKN2A:c.377T>A (p.V126D)) that had no evidence of melanoma versus those individuals that had a history of melanoma. Most interestingly, expression of miR-125b was 1.5-fold higher in those individuals with the p16 mutation (CDKN2A:c.377T>A (p.V126D)) that had no evidence of melanoma as compared to individuals with this mutation that had a history of melanoma ( $p$ value of 0.025). In Table 5 and Figure 3 we show the comparison in miRNA expression between control individuals and patients with metastatic melanoma. Most interestingly, miR-17, miR-19a, miR-21, miR-126 and miR-149 were expressed at 1.8-fold, 2.3-fold, 1.7-fold, 2.8-fold and 3.9-fold higher levels, respectively, in patients with metastatic melanoma ( $p$ values of $0.044,0.015$, $0.038,0.040$ and 0.021 , respectively).

Table 3. MiRNA expression in plasma-derived exosomes from p16 mutation carriers.

\begin{tabular}{cccc}
\hline MiRNA & Control & p16 Carriers & $p$ Value \\
\hline hsa-let-7b & $0.118 \pm 0.001$ & $0.104 \pm 0.012$ & 0.217 \\
hsa-let-7g & $0.056 \pm 0.007$ & $0.051 \pm 0.011$ & 0.350 \\
hsa-miR-125b & $1.319 \pm 0.125$ & $1.251 \pm 0.150$ & 0.368 \\
hsa-miR-126 & $0.113 \pm 0.019$ & $0.127 \pm 0.018$ & 0.425 \\
hsa-miR-128 & $2.034 \pm 0.210$ & $1.826 \pm 0.206$ & 0.242 \\
hsa-miR-137 & $0.052 \pm 0.005$ & $0.045 \pm 0.006$ & 0.252 \\
hsa-miR-148a & $0.094 \pm 0.011$ & $0.083 \pm 0.008$ & 0.224 \\
hsa-miR-149 & $0.024 \pm 0.004$ & $0.028 \pm 0.006$ & 0.310 \\
hsa-miR-17 & $0.101 \pm 0.17$ & $0.097 \pm 0.013$ & 0.418 \\
hsa-miR-199a & $0.017 \pm 0.004$ & $0.016 \pm 0.010$ & 0.451 \\
hsa-miR-19a & $0.421 \pm 0.067$ & $0.409 \pm 0.053$ & 0.446 \\
hsa-miR-19b & $0.558 \pm 0.090$ & $0.543 \pm 0.077$ & 0.450 \\
hsa-miR-20b & $0.123 \pm 0.020$ & $0.107 \pm 0.012$ & 0.273 \\
hsa-miR-21 & $0.775 \pm 0.074$ & $0.789 \pm 0.054$ & 0.441 \\
hsa-miR-221 & $0.335 \pm 0.030$ & $0.311 \pm 0.023$ & 0.273 \\
hsa-miR-222 & $0.589 \pm 0.062$ & $0.519 \pm 0.062$ & 0.182 \\
hsa-miR-23a & $0.520 \pm 0.095$ & $0.473 \pm 0.072$ & 0.350 \\
hsa-miR-29a & $0.625 \pm 0.054$ & $0.593 \pm 0.044$ & 0.323 \\
hsa-miR-423-3p & $0.088 \pm 0.014$ & $0.078 \pm 0.006$ & 0.264 \\
hsa-miR-92a & $0.341 \pm 0.053$ & $0.306 \pm 0.034$ & 0.292 \\
\hline
\end{tabular}


Table 4. MiRNA expression in plasma-derived exosomes from p16 mutation carriers with or without melanoma.

\begin{tabular}{cccc}
\hline MiRNA & p16 No Melanoma & p16 with Melanoma & $p$ Value \\
\hline hsa-let-7b & $0.119 \pm 0.017$ & $0.094 \pm 0.016$ & 0.162 \\
hsa-let-7g & $0.048 \pm 0.007$ & $0.052 \pm 0.018$ & 0.422 \\
hsa-miR-125b & $1.571 \pm 0.081$ & $1.052 \pm 0.214$ & 0.025 \\
hsa-miR-126 & $0.140 \pm 0.007$ & $0.120 \pm 0.030$ & 0.274 \\
hsa-miR-128 & $1.908 \pm 0.223$ & $1.774 \pm 0.315$ & 0.368 \\
hsa-miR-137 & $0.036 \pm 0.004$ & $0.051 \pm 0.009$ & 0.103 \\
hsa-miR-148a & $0.089 \pm 0.004$ & $0.079 \pm 0.013$ & 0.256 \\
hsa-miR-149 & $0.021 \pm 0.002$ & $0.032 \pm 0.010$ & 0.172 \\
hsa-miR-17 & $0.111 \pm 0.012$ & $0.088 \pm 0.021$ & 0.187 \\
hsa-miR-199a & $0.020 \pm 0.006$ & $0.013 \pm 0.002$ & 0.183 \\
hsa-miR-19a & $0.404 \pm 0.037$ & $0.411 \pm 0.087$ & 0.471 \\
hsa-miR-19b & $0.485 \pm 0.053$ & $0.579 \pm 0.123$ & 0.252 \\
hsa-miR-20b & $0.121 \pm 0.016$ & $0.099 \pm 0.018$ & 0.191 \\
hsa-miR-21 & $0.757 \pm 0.046$ & $0.809 \pm 0.085$ & 0.301 \\
hsa-miR-221 & $0.354 \pm 0.029$ & $0.285 \pm 0.031$ & 0.068 \\
hsa-miR-222 & $0.577 \pm 0.046$ & $0.483 \pm 0.061$ & 0.125 \\
hsa-miR-23a & $0.542 \pm 0.069$ & $0.430 \pm 0.110$ & 0.205 \\
hsa-miR-29a & $0.544 \pm 0.061$ & $0.623 \pm 0.061$ & 0.193 \\
hsa-miR-423-3p & $0.094 \pm 0.012$ & $0.068 \pm 0.005$ & 0.063 \\
hsa-miR-92a & $0.382 \pm 0.075$ & $0.258 \pm 0.018$ & 0.088 \\
\hline
\end{tabular}

Table 5. MiRNA expression in plasma-derived exosomes from patients with metastatic melanoma.

\begin{tabular}{cccc}
\hline MiRNA & Control & Metastatic Melanoma & $p$ Value \\
\hline hsa-let-7b & $0.118 \pm 0.001$ & $0.192 \pm 0.066$ & 0.146 \\
hsa-let-7g & $0.056 \pm 0.007$ & $0.065 \pm 0.027$ & 0.378 \\
hsa-miR-125b & $1.319 \pm 0.125$ & $1.219 \pm 0.468$ & 0.420 \\
hsa-miR-126 & $0.113 \pm 0.019$ & $0.320 \pm 0.096$ & 0.040 \\
hsa-miR-128 & $2.034 \pm 0.210$ & $1.420 \pm 0.322$ & 0.063 \\
hsa-miR-137 & $0.052 \pm 0.005$ & $0.102 \pm 0.030$ & 0.067 \\
hsa-miR-148a & $0.094 \pm 0.011$ & $0.126 \pm 0.028$ & 0.150 \\
hsa-miR-149 & $0.024 \pm 0.004$ & $0.094 \pm 0.030$ & 0.021 \\
hsa-miR-17 & $0.101 \pm 0.17$ & $0.181 \pm 0.040$ & 0.044 \\
hsa-miR-199a & $0.017 \pm 0.004$ & $0.028 \pm 0.006$ & 0.084 \\
hsa-miR-19a & $0.421 \pm 0.067$ & $0.986 \pm 0.222$ & 0.015 \\
hsa-miR-19b & $0.558 \pm 0.090$ & $1.203 \pm 0.290$ & 0.259 \\
hsa-miR-20b & $0.123 \pm 0.020$ & $0.202 \pm 0.046$ & 0.071 \\
hsa-miR-21 & $0.775 \pm 0.074$ & $1.305 \pm 0.268$ & 0.038 \\
hsa-miR-221 & $0.335 \pm 0.030$ & $0.390 \pm 0.085$ & 0.279 \\
hsa-miR-222 & $0.589 \pm 0.062$ & $0.680 \pm 0.123$ & 0.258 \\
hsa-miR-23a & $0.520 \pm 0.095$ & $0.773 \pm 0.208$ & 0.142 \\
hsa-miR-29a & $0.625 \pm 0.054$ & $0.795 \pm 0.150$ & 0.154 \\
hsa-miR-423-3p & $0.088 \pm 0.014$ & $0.082 \pm 0.010$ & 0.369 \\
hsa-miR-92a & $0.341 \pm 0.053$ & $0.267 \pm 0.036$ & 0.133 \\
\hline
\end{tabular}



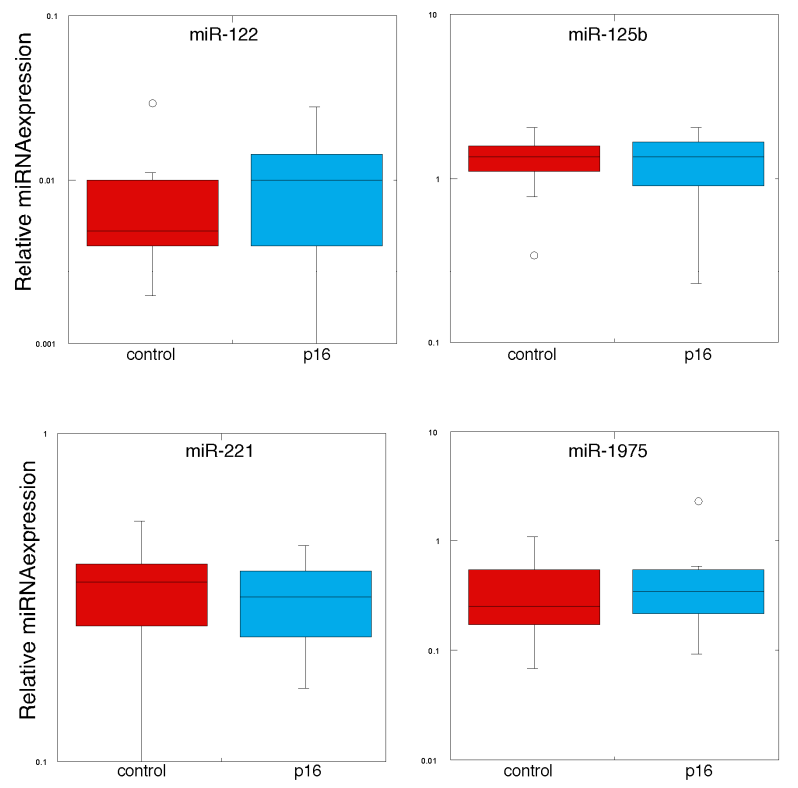

Figure 2. MiRNA expression in plasma-derived exosomes from individuals with the p16 mutation and normal volunteers. RNA was prepared from plasma-derived exosomes from individuals with the p16 mutation (CDKN2A:c.377T>A (p.V126D)) and normal volunteers. MiRNA expression was determined by qPCR $(n=3)$ and normalized to the spiked-in levels of Cel39.
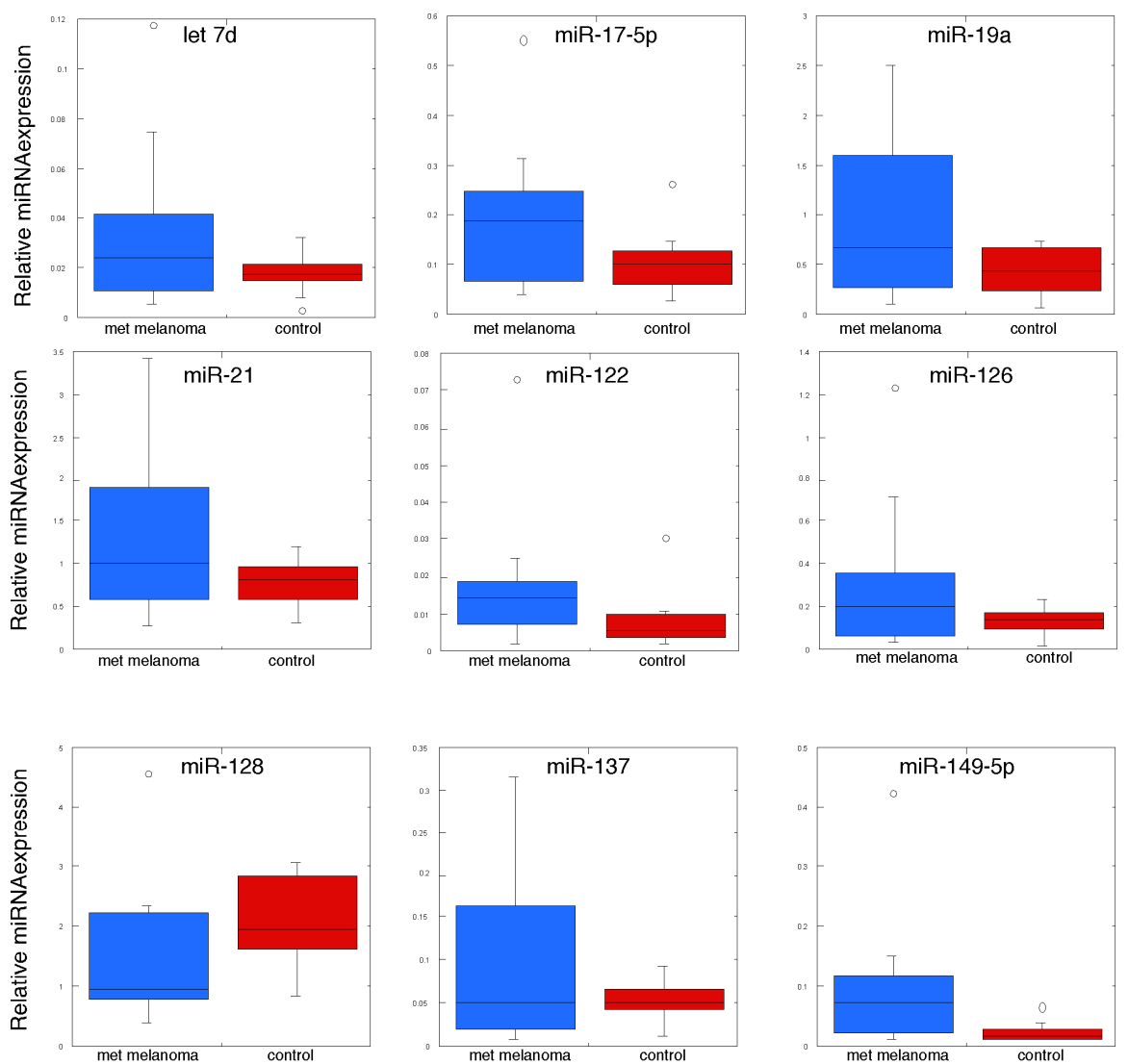

Figure 3. MiRNA expression in plasma-derived exosomes from individuals with metastatic melanoma and normal volunteers. RNA was prepared from plasma-derived exosomes from individuals with metastatic melanoma and normal volunteers. MiRNA expression was determined by qPCR $(n=3)$ and normalized to the spiked-in levels of Cel39. 

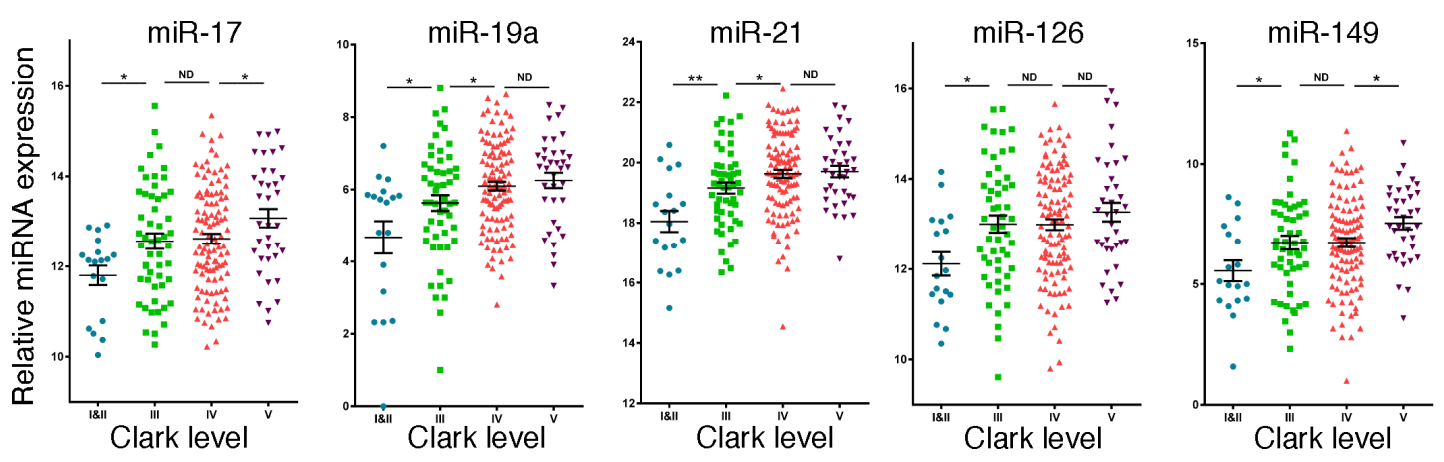

Figure 4. High expression of miR-17, miR-19a, miR-21, miR-126 and miR-149 is associated with melanoma tumor grade. Expression of miR-17, miR-19a, miR-21, miR-126 and miR-149 in the TCGA database for 216 independent melanoma patient samples according to Clark level (Level 1 is the least aggressive and Level $\mathrm{V}$ is the most aggressive).

\subsection{Expression of Potential miRNA Biomarkers in Melanoma}

Based on the results from the above studies, we then sought to determine whether miRNAs, which were differentially expressed in plasma exosomes derived from patients with metastatic melanoma, were also differentially expressed in melanoma tumor tissue. Therefore, we examined the TCGA database for miRNA expression in 216 melanoma specimens, which were classified according to Clark level (level I/II is minimally invasive cancer and level V is the most highly invasive form). As shown in Figure 4, low expression of miR-17, miR-19a, miR-21, miR-126 and miR-149 was found in thinner melanoma (Clark level I/II) and high expression was found in thicker melanoma (Clark level III, IV and V). These results provide additional evidence that these exosomal miRNAs are associated with the occurrence of melanoma in situ. Such melanoma samples include the tumor cells as well as the cells in tumor microenvironment that coordinately regulate tumorigenesis.

\subsection{The Potential Biological Functions of the miRNAs Upregulated in Metastatic Melanoma}

To investigate the potential biological functions of the miRNAs upregulated in metastatic melanoma, the target sites of miR-17-5p, miR-19a-3p, miR-149-5p, miR-21 and miR-126-3p were mapped to the 3-UTRs of a panel of genes that have been previously found to be associated with melanoma progression [21-23]. Forty genes associated with melanoma progression were found to be putative targets of these miRNAs (Table 6). To gain insights into the biological pathways that these putative miRNA targets may affect, we performed gene set enrichment analysis using the Molecular Signatures Database v5.0 [24], which is a computational method used to identify over-represented gene sets with defined biological meanings [25]. As shown in Figure 5, the most significantly enriched gene sets contain genes downregulated by ultraviolet (UV) irradiation (i.e., genes included in the ENK_UV_RESPONSE_EPIDERMIS_DN and ENK_UV_RESPONSE_KERATINOCYTE_DN gene sets), targeted by the tumor protein p53 (TP53)/retinoblastoma protein (RB1) (i.e., genes included in the MARTINEZ_RB1_AND_TP53_TARGETS_UP, MARTINEZ_RB1_TARGETS_UP and MARTINEZ_TP53_TARGETS_UP gene sets) and genes related to the tumor growth factor-beta (TGFB)/SMAD pathways (i.e., genes included in the PANGAS_TUMOR_SUPPRESSION_BY_SMAD1 _AND_SMAD5_UP gene set). 
Table 6. Putative targets of miRNAs upregulated in metastatic melanoma.

\begin{tabular}{|c|c|c|c|c|c|}
\hline Genes & & miR-17 & $\operatorname{miR-19a}$ & $\operatorname{miR}-149$ & $\operatorname{miR}-21$ \\
\hline ADD3 & adducin 3 (gamma) & & & $\mathrm{y}$ & \\
\hline ARL4C & ADP-ribosylation factor-like $4 \mathrm{C}$ & $\mathrm{y}$ & & & \\
\hline BCL11A & $\begin{array}{l}\text { B-cell CLL/lymphoma 11A } \\
\text { (zinc finger protein) }\end{array}$ & & $\mathrm{y}$ & & y \\
\hline BCL11B & $\begin{array}{l}\text { B-cell CLL/lymphoma 11B } \\
\text { (zinc finger protein) }\end{array}$ & $\mathrm{y}$ & & & $\mathrm{y}$ \\
\hline CD34 & CD34 molecule & & & $\mathrm{y}$ & \\
\hline CDS1 & $\begin{array}{l}\text { CDP-diacylglycerol synthase } \\
\text { (phosphatidate cytidylyltransferase) } 1\end{array}$ & & $\mathrm{y}$ & & \\
\hline CXCL12 & $\begin{array}{l}\text { chemokine (C-X-C motif) ligand } 12 \\
\text { (stromal cell-derived factor } 1)\end{array}$ & & $\mathrm{y}$ & & \\
\hline CYBB & cytochrome b-245, beta polypeptide & $\mathrm{y}$ & & & \\
\hline DSC3 & desmocollin 3 & & & $\mathrm{y}$ & \\
\hline EREG & epiregulin & $\mathrm{y}$ & $\mathrm{y}$ & & \\
\hline ESR1 & estrogen receptor 1 & $\mathrm{y}$ & $\mathrm{y}$ & & \\
\hline FAT2 & FAT tumor suppressor homolog 2 & $\mathrm{y}$ & & & \\
\hline FBLN1 & fibulin 1 & $\mathrm{y}$ & & $\mathrm{y}$ & \\
\hline GJA1 & gap junction protein, alpha 1, $43 \mathrm{kDa}$ & $\mathrm{y}$ & $\mathrm{y}$ & & \\
\hline GRHL2 & grainyhead-like 2 (Drosophila) & $\mathrm{y}$ & & & \\
\hline HLF & hepatic leukemia factor & $\mathrm{y}$ & $\mathrm{y}$ & & \\
\hline ID2 & $\begin{array}{l}\text { inhibitor of DNA binding 2, dominant } \\
\text { negative helix-loop-helix protein }\end{array}$ & & $\mathrm{y}$ & & \\
\hline LRIG1 & $\begin{array}{l}\text { leucine-rich repeats and } \\
\text { immunoglobulin-like domains } 1\end{array}$ & $\mathrm{y}$ & $\mathrm{y}$ & & \\
\hline LRRK1 & leucine-rich repeat kinase 1 & & $\mathrm{y}$ & & \\
\hline LTB4R & leukotriene B4 receptor & & & $\mathrm{y}$ & \\
\hline MACF1 & microtubule-actin crosslinking factor 1 & & $\mathrm{y}$ & & \\
\hline MBNL1 & muscleblind-like (Drosophila) & $\mathrm{y}$ & $\mathrm{y}$ & & $\mathrm{y}$ \\
\hline MGEA5 & $\begin{array}{l}\text { meningioma expressed antigen } 5 \\
\text { (hyaluronidase) }\end{array}$ & $\mathrm{y}$ & & & \\
\hline MPZL2 & myelin protein zero-like 2 & $\mathrm{y}$ & & & \\
\hline NFATC3 & $\begin{array}{l}\text { nuclear factor of activated T-cells, } \\
\text { cytoplasmic, calcineurin-dependent } 3\end{array}$ & & & $\mathrm{y}$ & \\
\hline NLRP3 & NLR family, pyrin domain containing 3 & $\mathrm{y}$ & & & \\
\hline NMT2 & $\mathrm{N}$-myristoyltransferase 2 & & $\mathrm{y}$ & & \\
\hline NTRK2 & $\begin{array}{l}\text { neurotrophic tyrosine kinase, receptor, } \\
\text { type } 2\end{array}$ & $\mathrm{y}$ & & $\mathrm{y}$ & \\
\hline PAIP2B & $\begin{array}{l}\text { poly(A) binding protein interacting } \\
\text { protein } 2 B\end{array}$ & & & $\mathrm{y}$ & $\mathrm{y}$ \\
\hline PTGER3 & prostaglandin E receptor 3 (subtype EP3) & $\mathrm{y}$ & & & \\
\hline PTGS1 & $\begin{array}{l}\text { prostaglandin-endoperoxide synthase } 1 \\
\text { (prostaglandin G/H synthase and } \\
\text { cyclooxygenase) }\end{array}$ & $\mathrm{y}$ & & & \\
\hline RAPGEFL1 & $\begin{array}{l}\text { Rap guanine nucleotide exchange factor } \\
\text { (GEF)-like } 1\end{array}$ & $\mathrm{y}$ & $\mathrm{y}$ & & \\
\hline RORA & RAR-related orphan receptor A & $\mathrm{y}$ & $\mathrm{y}$ & $\mathrm{y}$ & \\
\hline RTN1 & reticulon 1 & & $\mathrm{y}$ & & \\
\hline TCF4 & transcription factor 4 & $\mathrm{y}$ & & & \\
\hline TMEM45A & transmembrane protein $45 \mathrm{~A}$ & & $\mathrm{y}$ & & \\
\hline TNFRSF25 & $\begin{array}{l}\text { tumor necrosis factor receptor } \\
\text { superfamily, member } 25\end{array}$ & & & $\mathrm{y}$ & \\
\hline TP63 & tumor protein $\mathrm{p} 63$ & $\mathrm{y}$ & & $\mathrm{y}$ & \\
\hline TXNIP & thioredoxin interacting protein & $\mathrm{y}$ & & & \\
\hline ZFP36L2 & zinc finger protein $36, \mathrm{C} 3 \mathrm{H}$ type-like 2 & & & & $\mathrm{y}$ \\
\hline
\end{tabular}

No binding sites of miR-126 were found in the $3^{\prime}$-UTRs of the genes associated with melanoma progression. 


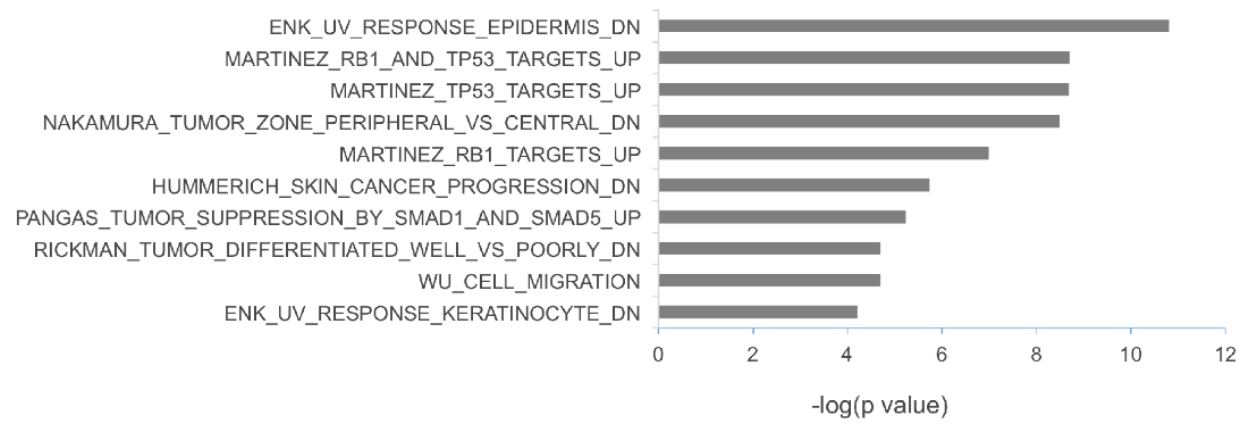

Figure 5. Enriched gene sets of putative targets of miRNAs upregulated in metastatic melanoma. The conserved target sites of miR-17-5p, miR-19a-3p, miR-149-5p, miR-21 and miR-126-3p were mapped to the 3-UTRs of a panel of genes that have been associated with melanoma progression according to TargetScan V6.2. Gene set enrichment analysis of putative miRNA targets was conducted by using the Molecular Signatures Database v5.0.

\section{Discussion}

To date, over 1800 human miRNAs have been identified, and miRNAs are predicted to control over $60 \%$ of all human genes [2,26]. MiRNAs regulate a wide variety of cellular processes, including cancer. The miRNAs differentially expressed in patients with metastatic melanoma may play important roles in tumor progression and metastasis, as well as be explored as diagnostic biomarkers. Exosomal miRNAs may transfer or shuttle signals between cancer cells and normal cells, and may contribute to malignant transformation. Differentially-expressed exosomal miRNA has now been demonstrated for many forms of cancer [27], and a recent study has shown that a panel of 5 miRNAs can be used to estimate risk of recurrence in stage II melanoma patients [28]. The measurement of tumor-derived miRNAs in serum or plasma may be an important approach to cancer detection [20]. In a previous study, higher levels of circulating miR-221 were found in serum samples of malignant melanoma patients as compared to healthy volunteers [29].

In the present study, we investigated miRNA signatures of plasma-derived exosomes from familial and sporadic melanoma patients and unaffected family members. Several miRNAs were differentially expressed in plasma-derived exosomes, which may form the basis for future studies on their applicability as predisposition biomarkers and potential chemoprevention targets. An important aspect of our studies was the finding that miR-17, miR-19a, miR-21, miR-126 and miR-149 were expressed at higher levels in plasma-derived exosomes from patients with metastatic melanoma. Many of these miRNAs have been associated with various cancers, and in some cases with melanoma specifically. For example, using a high-throughput approach, miR-17 was identified as a potential oncogenic miRNA in melanoma [30]. Previous studies demonstrated that miR-17 is highly expressed in leukemia and lung cancer, and it promotes cell proliferation by targeting p21 [31,32] as well as PTEN and RB [33,34]. Also, increased expression of miR-19a leads to increased melanoma invasiveness [35]. MiR-19a is an important member of the oncogenic miR-17-92 cluster. MiR-19a is upregulated in acute myeloid leukemia, colorectal cancer and gastric cancer, and is believed to act through promoting tumor growth and metastasis [36,37]. MiR-21 is frequently upregulated in human tumor cells where it appears to play an important role in the oncogenic process through its association with increased proliferation, low apoptosis, high invasion and metastatic potential [38-44]. However, miR-21 is also upregulated in the inflammatory response, which also may play an important role in tumor progression as well as in tumor elimination (reviewed in [45]). We recently found that IFN upregulated miR-21 expression in both melanoma and prostate cancer cells, which diminished their apoptotic sensitivity [46,47]. In contrast, knockdown (KD) of miR-21 expression enhanced apoptotic sensitivity to IFN as well as to several chemotherapeutic agents. Consistent with these findings, miR-21 inhibition in human melanoma cells increases expression of the PTEN target gene, 
leading to suppression of AKT phosphorylation and subsequently increased Bax/Bcl-2 ratio [48]. Most interestingly, using mouse B16 melanoma, we found that while the parent cell line exclusively formed large tumors in the lungs of tail-vein injected mice, miR-21 KD cells formed only small lung tumors [47], and mice injected with miR-21 KD cells exhibited markedly prolonged animal survival. Elevated miR-126 expression has been observed in normal melanocytes and primary melanoma cell lines, while it was reportedly reduced in metastatic melanoma [49]. Overexpression of miR-126 was found to enhance melanogenesis. MiR-149 is upregulated in melanoma cells and is expressed in response to p53 activation [50]. However, miR-149 provides a mechanism to bypass the induction of apoptosis by p53 activation by directly targeting glycogen synthetase- $3 \alpha$ and thereby stabilizing MCL-1.

Consistent with the reported function of these miRNAs in regulating cell proliferation and metastatic potential, target site mapping to genes associated with melanoma progression suggests that miR-17-5p, miR-19a-3p, miR-149-5p and miR-21 play a role in modulating cell response to TP53/RB1 activation and TGF $\beta /$ SMAD signaling pathways. Since these pathways play an important role in regulating the G1/S checkpoint of normal melanocytes and are major regulators of melanocyte transformation [51,52], the upregulation of miRNAs controlling TP53/RB1 activation and TGF $\beta /$ SMAD signaling pathways may contribute to G1/S checkpoint abnormalities that are frequently observed during melanoma progression. Since these signaling pathways are critical to the malignant process, further studies will be needed to define the roles of these pathways directly in melanoma cells themselves and in the stromal cells surrounding the tumor.

Although we hypothesized that genetically predisposed familial melanoma patients with/without evidence of disease might share their miRNA expression profile with sporadic metastatic melanoma patients, no major differences between p16 mutation (CDKN2A:c.377T>A (p.V126D)) gene carriers and normal controls were detected. There are several possible explanations for our inability to discern miRNAs that are risk biomarkers in cohorts of familial melanoma. These possibilities include: (1) differences in miRNA profiles of the cohorts in our p16 families are too small to be detected with the sample size available in this work (although relative to the uniqueness of the cohort, the number of samples used in this study is large); (2) the miRNA profile of an affected p16 mutation carrier (CDKN2A:c.377T >A (p.V126D)) is not significantly different from a carrier that has not had a melanoma or from a normal control; (3) other p16 mutations such as the CDKN2A:c.259G>T (p.R87P) mutation $[16,53]$ may more closely share the miRNA pattern associated with the pattern observed in plasma-derived exosomes from sporadic malignant melanoma patients; and (4) the metastatic patients may have had circulating tumor cells which contributed and further amplified the differences seen in exosomes, and tumor exosomes are different from those that might be associated with genetic predisposition to melanoma. Our findings are consistent with the occurrence of miRNA dysregulation in metastatic melanoma. Therefore, this technology might be better suited for detecting recurrent metastatic melanoma following therapeutic intervention.

Taken together, our results show that we have been able to identify several circulating miRNAs that are up-regulated in plasma-derived exosomes from patients with sporadic metastatic melanoma. While the increased expression of these unique miRNAs in the plasma-derived exosomes may be due, in part, to the occurrence of tumor cells in the circulation, these circulating miRNAs have prognostic potential in patients with metastatic melanoma. Future studies should be directed at discerning the role of these individual miRNAs in melanoma progression and metastasis, particularly in response to therapy.

\section{Materials and Methods}

\subsection{Plasma}

Archived citrate-treated plasma samples from 8 individuals with CDKN2A/p16 mutations with a history of melanoma, 5 individuals with CDKN2A/p16 mutations with no history of melanoma, 
13 spouse controls and 10 patients with metastatic melanoma were obtained from the Huntsman Cancer Institute of the University of Utah. All subjects gave their informed consent for inclusion before they participated in the study. The study was conducted in accordance with the Declaration of Helsinki, and the protocol was approved by the Ethics Committee of the University of Utah (7916-00). General clinical patient information is shown in Table 1.

\subsection{Preparation of Plasma-Derived Exosomes and Isolation of RNA}

Following a protocol previously established in our group [8], citrate-treated plasma was incubated at $37^{\circ} \mathrm{C}$ for $15 \mathrm{~min}$ with Thromboplastin-D to remove clotting factors, and centrifuged $\left(8000 \times \mathrm{g}\right.$ for $15 \mathrm{~min}$ at $\left.22{ }^{\circ} \mathrm{C}\right)$. The resultant supernatant $(1.2 \mathrm{~mL})$ was mixed by inversion with $140 \mu \mathrm{L}$ of ExoQuick solution (System Biosciences, Mountain View, CA, USA) overnight at $4{ }^{\circ} \mathrm{C}$. The ExoQuick/plasma mixture was centrifuged $\left(1500 \times g\right.$ for $15 \mathrm{~min}$ at $\left.22^{\circ} \mathrm{C}\right)$, and the exosomal pellet was washed twice with PBS. The exosomal pellet was resuspended in $700 \mu \mathrm{L}$ of Qiazol (containing $0.05 \mathrm{fmol} / \mathrm{mL}$ of Cel39 for miRNA normalization) and incubated for $5 \mathrm{~min}$ at $22{ }^{\circ} \mathrm{C}$. The RNA was extracted by addition of $140 \mu \mathrm{L}$ of chloroform by incubating for $5 \mathrm{~min}$ at RT. After centrifugation at $12,000 \times \mathrm{g}$ for $15 \mathrm{~min}$ at $4{ }^{\circ} \mathrm{C}, 280 \mu \mathrm{L}$ of the upper aqueous phase was transferred to a new tube, mixed with $420 \mu \mathrm{L}$ of $100 \%$ ethanol and loaded on a miRNeasy MinElute spin column. After centrifugation at $8000 \times g$ for $15 \mathrm{~s}$ at $22{ }^{\circ} \mathrm{C}$, the column was washed three times with RNeasy buffer RWT followed by centrifugation. The RNA was concentrated to a final volume of $20 \mu \mathrm{L}$ with RNase-free water with an Amicon Ultra YM-3 filter by centrifugation at $14,000 \times \mathrm{g}$ at $22{ }^{\circ} \mathrm{C}$ for $45 \mathrm{~min}$.

\section{3. miRNA Expression Profiling}

Microarray analysis on RNA prepared from plasma-derived exosomes was performed using the human V1 miRNA assay kit (NanoString Technologies, Seattle, WA, USA) that contains $~ 700$ human miRNAs. The integrity and quantity of the RNA was assessed using the Agilent 2100 Bioanalyzer and RNA 6000 Pico Kit (Agilent Technologies, Santa Clara, CA, USA). In brief, total RNA was mixed with pairs of capture and reporter probes, hybridized on the nCounter Prep Station, and purified complexes were quantified on the nCounter digital analyzer. To account for differences in hybridization and purification, data were normalized to the average counts for all control spikes in each sample and analyzed with nSolver software.

\section{4. miRNA Expression Using SYBR Green Real Time PCR}

PolyA-tailed total RNA was prepared from plasma-derived exosomes using (polyA) polymerase (NEB; Ipswich, MA, USA) at $37{ }^{\circ} \mathrm{C}$ for $1 \mathrm{~h}$ as previously described [46]. The final reaction mixture was extracted with phenol/chloroform, precipitated with isopropanol, redissolved in diethylpyrocarbonate (DEPC)-treated water, and was reverse-transcribed into first-strand cDNA using Superscript III transcriptase (Invitrogen) with the oligo-dT adapter primer 5'GCGAGCACAGAATTAATACGACTCACTATAGGTTTTTTTTTTTTVN3'. For PCR, 40 ng of cDNA was used as a template in each reaction. The reverse primer was from the adapter sequence: 5'GCGAGCACAGAATTAATACGACTCAC3' and the forward primers were specific to miRNA mature sequences (shown in Table 2). The SYBR Green-based real-time PCR was performed to quantify miRNA expression, and Cel39 was used to normalize miRNA expression. The expression data was normalized to the expression of the spiked in C. elegans miRNA (Cel39) as a normalizing control as previously described [20].

\subsection{TCGA Data Query}

To examine the relationship between miR-17, miR-19a, miR-21, miR-126 and miR-149 expression in human cancer specimens from cutaneous melanoma, we queried the TCGA data portal [54] for all samples with Level 3 miRNA expression data available, as well as the accompanying clinical data. 
The data set was filtered for samples having expression data for these selected miRNAs and clinical data, yielding a final set of 216 melanoma independent patient samples.

\subsection{Statistical Analysis}

At least two independent PCR experiments were performed in triplicate, and data are presented as means $\pm \mathrm{sd}$. ANOVA and post-hoc least significant difference analysis or Student $t$ tests were performed using Graphpad InStat 3 software, with $p$-values $<0.05$ considered statistically significant.

Acknowledgments: This work was supported by National Cancer Institute HHSN261200433000C and by funds from the Muirhead Chair Endowment at the University of Tennessee Health Science Center. We thank John F. Quackenbush for his assistance in preparing plasma-derived exosomes and in the initial miRNA analysis.

Author Contributions: Kenneth F. Grossmann, Levy Kopelovich, Sancy A. Leachman and Lawrence M. Pfeffer conceived and designed the experiments; Susan R. Pfeffer and Chuan He Yang performed the experiments; Susan R. Pfeffer, Kenneth F. Grossmann, Meiyun Fan, Pamela B. Cassidy, Chuan He Yang, Sancy A. Leachman and Lawrence M. Pfeffer analyzed the data; Chuan He Yang, Kenneth F. Grossmann, Meiyun Fan, Pamela B. Cassidy, Sancy A. Leachman and Lawrence M. Pfeffer contributed reagents/materials/analysis tools; Susan R. Pfeffer, Levy Kopelovich, Sancy A. Leachman and Lawrence M. Pfeffer wrote the paper.

Conflicts of Interest: The authors declare no conflict of interest. The founding sponsors had no role in the design of the study; in the collection, analyses, or interpretation of data; in the writing of the manuscript; or in the decision to publish the results.

\section{References}

1. Vasudevan, S.; Tong, Y.; Steitz, J.A. Switching from repression to activation: MicroRNAs can up-regulate translation. Science 2007, 318, 1931-1934. [CrossRef] [PubMed]

2. Bartel, D.P. MicroRNAs: Genomics, biogenesis, mechanism, and function. Cell 2004, 116, $281-297$. [CrossRef]

3. Cho, W.C. Oncomirs: The discovery and progress of microRNAs in cancers. Mol. Cancer 2007, 6, 60. [CrossRef] [PubMed]

4. Rabinowits, G.; Gercel-Taylor, C.; Day, J.M.; Taylor, D.D.; Kloecker, G.H. Exosomal microRNA: A diagnostic marker for lung cancer. Clin. Lung Cancer 2009, 10, 42-46. [CrossRef] [PubMed]

5. Thery, C.; Ostrowski, M.; Segura, E. Membrane vesicles as conveyors of immune responses. Nat. Rev. Immunol. 2009, 9, 581-593. [CrossRef] [PubMed]

6. Pegtel, D.M.; Cosmopoulos, K.; Thorley-Lawson, D.A.; van Eijndhoven, M.A.; Hopmans, E.S.; Lindenberg, J.L.; de Gruijl, T.D.; Wurdinger, T.; Middeldorp, J.M. Functional delivery of viral miRNAs via exosomes. Proc. Natl. Acad. Sci. USA 2010, 107, 6328-6333. [CrossRef] [PubMed]

7. Kottel, R.H.; Hoch, S.O.; Parsons, R.G.; Hoch, J.A. Serum ribonuclease activity in cancer patients. Br. J. Cancer 1978, 38, 280-286. [CrossRef] [PubMed]

8. Quackenbush, J.F.; Cassidy, P.B.; Pfeffer, L.M.; Boucher, K.M.; Hawkes, J.E.; Pfeffer, S.R.; Kopelovich, L.; Leachman, S.A. Isolation of circulating microRNAs from microvesicles found in human plasma. Methods Mol. Biol. 2014, 1102, 641-653. [PubMed]

9. Siegel, R.; Naishadham, D.; Jemal, A. Cancer statistics, 2012. CA Cancer J. Clin. 2012, 62, 10-29. [CrossRef] [PubMed]

10. Aoude, L.G.; Wadt, K.A.; Pritchard, A.L.; Hayward, N.K. Genetics of familial melanoma: 20 years after CDKN2A. Pigment Cell Melanoma Res. 2015, 28, 148-160. [CrossRef] [PubMed]

11. Eliason, M.J.; Larson, A.A.; Florell, S.R.; Zone, J.J.; Cannon-Albright, L.A.; Samlowski, W.E.; Leachman, S.A. Population-based prevalence of CDKN2A mutations in Utah melanoma families. J. Investig. Dermatol. 2006, 126, 660-666. [CrossRef] [PubMed]

12. Goldstein, A.M.; Chan, M.; Harland, M.; Hayward, N.K.; Demenais, F.; Bishop, D.T.; Azizi, E.; Bergman, W.; Bianchi-Scarra, G.; Bruno, W.; et al. Features associated with germline CDKN2A mutations: A genomel study of melanoma-prone families from three continents. J. Med. Genet. 2007, 44, 99-106. [CrossRef] [PubMed] 
13. Hodis, E.; Watson, I.R.; Kryukov, G.V.; Arold, S.T.; Imielinski, M.; Theurillat, J.P.; Nickerson, E.; Auclair, D.; Li, L.; Place, C.; et al. A landscape of driver mutations in melanoma. Cell 2012, 150, 251-263. [CrossRef] [PubMed]

14. Stott, F.J.; Bates, S.; James, M.C.; McConnell, B.B.; Starborg, M.; Brookes, S.; Palmero, I.; Ryan, K.; Hara, E.; Vousden, K.H.; et al. The alternative product from the human CDKN2A locus, p14(ARF), participates in a regulatory feedback loop with p53 and MDM2. EMBO J. 1998, 17, 5001-5014. [CrossRef] [PubMed]

15. Bishop, D.T.; Demenais, F.; Goldstein, A.M.; Bergman, W.; Bishop, J.N.; de Paillerets, B.; Chompret, A.; Ghiorzo, P.; Gruis, N.; Hansson, J.; et al. Geographical variation in the penetrance of CDKN2A mutations for melanoma. J. Natl. Cancer Inst. 2002, 94, 894-903. [CrossRef] [PubMed]

16. Fan, M.; Pfeffer, S.R.; Lynch, H.T.; Cassidy, P.; Leachman, S.; Pfeffer, L.M.; Kopelovich, L. Altered transcriptome signature of phenotypically normal skin fibroblasts heterozygous for CDKN2A in familial melanoma: Relevance to early intervention. Oncotarget 2013, 4, 128-141. [CrossRef] [PubMed]

17. Caramuta, S.; Egyhazi, S.; Rodolfo, M.; Witten, D.; Hansson, J.; Larsson, C.; Lui, W.O. MicroRNA expression profiles associated with mutational status and survival in malignant melanoma. J. Investig. Dermatol. 2010, 130, 2062-2070. [CrossRef] [PubMed]

18. Glud, M.; Klausen, M.; Gniadecki, R.; Rossing, M.; Hastrup, N.; Nielsen, F.C.; Drzewiecki, K.T. MicroRNA expression in melanocytic nevi: The usefulness of formalin-fixed, paraffin-embedded material for miRNA microarray profiling. J. Investig. Dermatol. 2009, 129, 1219-1224. [CrossRef] [PubMed]

19. Segura, M.F.; Belitskaya-Levy, I.; Rose, A.E.; Zakrzewski, J.; Gaziel, A.; Hanniford, D.; Darvishian, F.; Berman, R.S.; Shapiro, R.L.; Pavlick, A.C.; et al. Melanoma microRNA signature predicts post-recurrence survival. Clin. Cancer Res. 2010, 16, 1577-1586. [CrossRef] [PubMed]

20. Mitchell, P.S.; Parkin, R.K.; Kroh, E.M.; Fritz, B.R.; Wyman, S.K.; Pogosova-Agadjanyan, E.L.; Peterson, A.; Noteboom, J.; O'Briant, K.C.; Allen, A.; et al. Circulating microRNAs as stable blood-based markers for cancer detection. Proc. Natl. Acad. Sci USA 2008, 105, 10513-10518. [CrossRef] [PubMed]

21. Talantov, D.; Mazumder, A.; Yu, J.X.; Briggs, T.; Jiang, Y.; Backus, J.; Atkins, D.; Wang, Y. Novel genes associated with malignant melanoma but not benign melanocytic lesions. Clin. Cancer Res. 2005, 11, 7234-7242. [CrossRef] [PubMed]

22. Smith, A.P.; Hoek, K.; Becker, D. Whole-genome expression profiling of the melanoma progression pathway reveals marked molecular differences between nevi/melanoma in situ and advanced-stage melanomas. Cancer Biol. Ther. 2005, 4, 1018-1029. [CrossRef] [PubMed]

23. Jaeger, J.; Koczan, D.; Thiesen, H.J.; Ibrahim, S.M.; Gross, G.; Spang, R.; Kunz, M. Gene expression signatures for tumor progression, tumor subtype, and tumor thickness in laser-microdissected melanoma tissues. Clin. Cancer Res. 2007, 13, 806-815. [CrossRef] [PubMed]

24. Molecular Signatures Database v5.0. Available online: http://software.broadinstitute.org/gsea/index.jsp (accessed on 30 June 2015).

25. Subramanian, A.; Tamayo, P.; Mootha, V.K.; Mukherjee, S.; Ebert, B.L.; Gillette, M.A.; Paulovich, A.; Pomeroy, S.L.; Golub, T.R.; Lander, E.S.; et al. Gene set enrichment analysis: A knowledge-based approach for interpreting genome-wide expression profiles. Proc. Natl. Acad. Sci. USA 2005, 102, 15545-15550. [CrossRef] [PubMed]

26. Lim, L.P.; Lau, N.C.; Garrett-Engele, P.; Grimson, A.; Schelter, J.M.; Castle, J.; Bartel, D.P.; Linsley, P.S.; Johnson, J.M. Microarray analysis shows that some microRNAs downregulate large numbers of target mRNAs. Nature 2005, 433, 769-773. [CrossRef] [PubMed]

27. Reid, G.; Kirschner, M.B.; van Zandwijk, N. Circulating microRNAs: Association with disease and potential use as biomarkers. Crit. Rev. Oncol. Hematol. 2011, 80, 193-208. [CrossRef] [PubMed]

28. Friedman, E.B.; Shang, S.; de Miera, E.; Fog, J.U.; Teilum, M.W.; Ma, M.W.; Berman, R.S.; Shapiro, R.L.; Pavlick, A.C.; Hernando, E.; et al. Serum microRNAs as biomarkers for recurrence in melanoma. J. Trans. Med. 2012, 10, 155. [CrossRef] [PubMed]

29. Kanemaru, H.; Fukushima, S.; Yamashita, J.; Honda, N.; Oyama, R.; Kakimoto, A.; Masuguchi, S.; Ishihara, T.; Inoue, Y.; Jinnin, M.; et al. The circulating microRNA-221 level in patients with malignant melanoma as a new tumor marker. J. Dermatol. Sci. 2011, 61, 187-193. [CrossRef] [PubMed]

30. Greenberg, E.; Hershkovitz, L.; Itzhaki, O.; Hajdu, S.; Nemlich, Y.; Ortenberg, R.; Gefen, N.; Edry, L.; Modai, S.; Keisari, Y.; et al. Regulation of cancer aggressive features in melanoma cells by microRNAs. PLoS ONE 2011, 6, e18936. [CrossRef] [PubMed] 
31. Wong, P.; Iwasaki, M.; Somervaille, T.C.; Ficara, F.; Carico, C.; Arnold, C.; Chen, C.Z.; Cleary, M.L. The miR-17-92 microRNA polycistron regulates MLL leukemia stem cell potential by modulating p21 expression. Cancer Res. 2010, 70, 3833-3842. [CrossRef] [PubMed]

32. Rao, E.; Jiang, C.; Ji, M.; Huang, X.; Iqbal, J.; Lenz, G.; Wright, G.; Staudt, L.M.; Zhao, Y.; McKeithan, T.W.; et al. The miRNA-17 approximately 92 cluster mediates chemoresistance and enhances tumor growth in mantle cell lymphoma via pi3k/akt pathway activation. Leukemia 2012, 26, 1064-1072. [CrossRef] [PubMed]

33. Hayashita, Y.; Osada, H.; Tatematsu, Y.; Yamada, H.; Yanagisawa, K.; Tomida, S.; Yatabe, Y.; Kawahara, K.; Sekido, Y.; Takahashi, T. A polycistronic microRNA cluster, miR-17-92, is overexpressed in human lung cancers and enhances cell proliferation. Cancer Res. 2005, 65, 9628-9632. [CrossRef] [PubMed]

34. Ebi, H.; Sato, T.; Sugito, N.; Hosono, Y.; Yatabe, Y.; Matsuyama, Y.; Yamaguchi, T.; Osada, H.; Suzuki, M.; Takahashi, T. Counterbalance between $\mathrm{rb}$ inactivation and miR-17-92 overexpression in reactive oxygen species and DNA damage induction in lung cancers. Oncogene 2009, 28, 3371-3379. [CrossRef] [PubMed]

35. Levy, C.; Khaled, M.; Iliopoulos, D.; Janas, M.M.; Schubert, S.; Pinner, S.; Chen, P.H.; Li, S.; Fletcher, A.L.; Yokoyama, S.; et al. Intronic miR-211 assumes the tumor suppressive function of its host gene in melanoma. Mol. Cell 2010, 40, 841-849. [CrossRef] [PubMed]

36. Wu, Q.; Yang, Z.; An, Y.; Hu, H.; Yin, J.; Zhang, P.; Nie, Y.; Wu, K.; Shi, Y.; Fan, D. MiR-19a/b modulate the metastasis of gastric cancer cells by targeting the tumour suppressor MXD1. Cell Death Dis. 2014, 5, e1144. [CrossRef] [PubMed]

37. Lepore, I.; Dell'Aversana, C.; Pilyugin, M.; Conte, M.; Nebbioso, A.; de Bellis, F.; Tambaro, F.P.; Izzo, T.; Garcia-Manero, G.; Ferrara, F.; et al. HDAC inhibitors repress BARD1 isoform expression in acute myeloid leukemia cells via activation of miR-19a and/or b. PLoS ONE 2013, 8, e83018. [CrossRef] [PubMed]

38. Si, M.L.; Zhu, S.; Wu, H.; Lu, Z.; Wu, F.; Mo, Y.Y. MiR-21-mediated tumor growth. Oncogene 2007, 26, 2799-2803. [CrossRef] [PubMed]

39. Volinia, S.; Calin, G.A.; Liu, C.G.; Ambs, S.; Cimmino, A.; Petrocca, F.; Visone, R.; Iorio, M.; Roldo, C.; Ferracin, M.; et al. A microRNA expression signature of human solid tumors defines cancer gene targets. Proc. Natl. Acad. Sci. USA 2006, 103, 2257-2261. [CrossRef] [PubMed]

40. Folini, M.; Gandellini, P.; Longoni, N.; Profumo, V.; Callari, M.; Pennati, M.; Colecchia, M.; Supino, R.; Veneroni, S.; Salvioni, R.; et al. miR-21: An oncomir on strike in prostate cancer. Mol. Cancer 2010, 9, 12. [CrossRef] [PubMed]

41. Loffler, D.; Brocke-Heidrich, K.; Pfeifer, G.; Stocsits, C.; Hackermuller, J.; Kretzschmar, A.K.; Burger, R.; Gramatzki, M.; Blumert, C.; Bauer, K.; et al. Interleukin-6 dependent survival of multiple myeloma cells involves the stat3-mediated induction of microRNA-21 through a highly conserved enhancer. Blood 2007, 110, 1330-1333. [CrossRef] [PubMed]

42. Chan, J.A.; Krichevsky, A.M.; Kosik, K.S. MicroRNA-21 is an antiapoptotic factor in human glioblastoma cells. Cancer Res. 2005, 65, 6029-6033. [CrossRef] [PubMed]

43. Zhu, S.; Wu, H.; Wu, F.; Nie, D.; Sheng, S.; Mo, Y.Y. MicroRNA-21 targets tumor suppressor genes in invasion and metastasis. Cell Res. 2008, 18, 350-359. [CrossRef] [PubMed]

44. Wang, P.; Zou, F.; Zhang, X.; Li, H.; Dulak, A.; Tomko, R.J., Jr.; Lazo, J.S.; Wang, Z.; Zhang, L.; Yu, J. MicroRNA-21 negatively regulates Cdc25A and cell cycle progression in colon cancer cells. Cancer Res. 2009, 69, 8157-8165. [CrossRef] [PubMed]

45. Sheedy, F.J. Turning 21: Induction of miR-21 as a key switch in the inflammatory response. Front. Immunol. 2015, 6, 19. [CrossRef] [PubMed]

46. Yang, C.H.; Yue, J.; Fan, M.; Pfeffer, L.M. IFN induces miR-21 through a signal transducer and activator of transcription 3-dependent pathway as a suppressive negative feedback on IFN-induced apoptosis. Cancer Res. 2010, 70, 8108-8116. [CrossRef] [PubMed]

47. Yang, C.H.; Yue, J.; Pfeffer, S.R.; Handorf, C.R.; Pfeffer, L.M. MicroRNA miR-21 regulates the metastatic behavior of b16 melanoma cells. J. Biol. Chem. 2011, 286, 39172-39178. [CrossRef] [PubMed]

48. Jiang, L.; Lv, X.; Li, J.; Li, J.; Li, X.; Li, W.; Li, Y. The status of microRNA-21 expression and its clinical significance in human cutaneous malignant melanoma. Acta Histochem. 2012, 114, 582-588. [CrossRef] [PubMed] 
49. Felli, N.; Felicetti, F.; Lustri, A.M.; Errico, M.C.; Bottero, L.; Cannistraci, A.; de Feo, A.; Petrini, M.; Pedini, F.; Biffoni, M.; et al. miR-126\&126* restored expressions play a tumor suppressor role by directly regulating ADAM9 and MMP7 in melanoma. PLoS ONE 2013, 8, e56824. [CrossRef] [PubMed]

50. Jin, L.; Hu, W.L.; Jiang, C.C.; Wang, J.X.; Han, C.C.; Chu, P.; Zhang, L.J.; Thorne, R.F.; Wilmott, J.; Scolyer, R.A.; et al. MicroRNA-149*, a p53-responsive microRNA, functions as an oncogenic regulator in human melanoma. Proc. Natl. Acad. Sci. USA 2011, 108, 15840-15845. [CrossRef] [PubMed]

51. Sauroja, I.; Smeds, J.; Vlaykova, T.; Kumar, R.; Talve, L.; Hahka-Kemppinen, M.; Punnonen, K.; Jansen, C.T.; Hemminki, K.; Pyrhonen, S. Analysis of G(1)/S checkpoint regulators in metastatic melanoma. Genes Chromosomes Cancer 2000, 28, 404-414. [CrossRef]

52. Perrot, C.Y.; Javelaud, D.; Mauviel, A. Insights into the transforming growth factor-beta signaling pathway in cutaneous melanoma. Ann. Dermatol. 2013, 25, 135-144. [CrossRef] [PubMed]

53. Lynch, H.T.; Fusaro, R.M.; Lynch, J.F.; Brand, R. Pancreatic cancer and the fammm syndrome. Fam. Cancer 2008, 7, 103-112. [CrossRef] [PubMed]

54. TCGA Data Portal. Available online: https://tcga-data.nci.nih.gov/tcga/tcgaHome2.jsp (accessed on 23 July 2015).

(C) 2015 by the authors; licensee MDPI, Basel, Switzerland. This article is an open access article distributed under the terms and conditions of the Creative Commons by Attribution (CC-BY) license (http://creativecommons.org/licenses/by/4.0/). 